\title{
Postpartum psychosis - case report on effective treatment of electroconvulsive therapy in a patient with a history of neuroleptic malignant syndrome
}

\author{
Psychoza poporodowa - opis przypadku skutecznego leczenia elektrowstrzasami \\ u pacjentki ze złośliwym zespołem neuroleptycznym $w$ wywiadzie
}

Bogdan W. Stefanowski, Anna Z. Antosik-Wójcińska, Julia Jeschke, Monika Dominiak, Łukasz Święcicki

\begin{abstract}
In this paper, we present a case of a 31-year-old patient with postpartum psychosis of an unusual course. In patients with antipsychotics, there have been significant complications of treatment in the form of a neuroleptic malignant syndrome. Because of the complications of pharmacological treatment, it was decided to withdraw
\end{abstract}

antipsychotics and to use electroconvulsive therapy. Propofol was used for the anaesthesia of the patient; cisatracurium was used for muscle relaxation. In case of neuroleptic malignant syndrome, succinylcholine is contraindicated because of the increased risk of malignant hyperthermia. Due to the use of long-term anaesthetic agents, the patient required temporary intubation and respiratory support. A total of 8 ECT procedures were performed, complete disappearance of positive symptoms was achieved. After electroconvulsive treatment, aripiprazole $5 \mathrm{mg} / \mathrm{d}$ was administered, no significant complications were observed. The patient was discharged home with full mental status.

\section{STRESZCZENIE}

W niniejszej pracy zaprezentowano przypadek 31-letniej pacjentki, u której wystąpiła psychoza poporodowa o nietypowym przebiegu. U pacjentki po zastosowaniu leków przeciwpsychotycznych doszło do istotnych powikłań leczenia, w postaci wystąpienia złośliwego zespołu neuroleptycznego. $Z$ powodu powikłań leczenia farmakologicznego zdecydowano o odstawieniu leków przeciwpsychotycznych i zastosowaniu terapii elektrowstrząsowej (EW). Do znieczulenia pacjentki zastosowano propofol, a w celu zwiotczenia mięśni cisatracurium. W przypadku wystąpienia złośliwego zespołu neuroleptycznego przeciwwskazane jest użycie sukcynocholiny ze względu na podwyższone ryzyko wystąpienia hipertermii złośliwej. Ze względu na użycie 
środków anestetycznych o dłuższym okresie działania, pacjentka wymagała czasowej intubacji i wspomagania oddechu. Wykonano łącznie osiem zabiegów EW, uzyskano całkowite ustąpienie objawów psychotycznych.
Po leczeniu elektrowstrząsowym włączono aripiprazol w dawce $5 \mathrm{mg} / \mathrm{d}$, nie obserwowano istotnych powikłań leczenia. Pacjentka została wypisana do domu w stanie pełnej poprawy stanu psychicznego.

\section{Introduction}

Mental disorders occurring in the postpartum period include the most common small changes in the mood, like baby blues, but also much more severe disorders, such as postpartum depression, and the rarest, but also the most severe - postpartum psychosis. Statistical data clearly show that postpartum (postnatal) psychosis is a rare phenomenon. In the general population, it is estimated at $0.1-0.2 \%$ of childbirths (Stewart et al. 1991). At the same time, it is the most severe of mental disorders occurring in the period after the birth of a child (Spinelli 2009, Jaeschke et al. 2012). For women with previously diagnosed bipolar disorder or previously experienced postpartum psychosis, its incidence is many times higher (Watkins 2009).

The clinical picture of patient suffering from postpartum psychosis shows a woman with "strange affect, withdrawn, distracted by auditory hallucinations, clumsy, confused and in a state of catatonia or euphoria, labile, with chaotic speech, disturbed, over-active" (Brockington 2004). Psychotic symptoms can occur in an isolated form or in combination with labile mood disorders. Some experts describe postpartum psychosis as a "psychosis with cognitive functioning disorganisation" or "psychotic affective disorders with delirium characteristics" (Spinelli 2009). According to a recent Dutch cohort study, depressive symptoms (41\%) are the dominant component of postpartum psychosis (Telles-Correia et al. 2018).

The risk of experiencing postpartum psychosis increases in women with positive family history of bipolar affective disorder or postpartum mental disorders. The risk of another psychotic episode as a result of childbirth is estimated at 30 to $50 \%$ (Kamperman et al. 2017). Despite the fact that postpartum psychosis was not listed as a separate diagnostic category in the DSM 5 classification (only "peripartum mood disorders with psychotic symptoms" were included), it seems that its clinical picture is so characteristic and different from other mental disorders occurring in the postpartum period that it should be considered as a separate disease being a source of health damage, suffering and functional impairment (Jablensky 2016, American Psychiatric Association 2013).

Due to its sudden onset and turbulent course, risk of suicide or infanticide, women with experience of postpartum psychosis require psychiatric hospitalisation (Koszewska 2010, Spinelli 2009).

The second medical problem discussed in the paper in the context of treatment of the described patient is neuroleptic malignant syndrome (NMS). NMS was first described in the literature by Delay and his co-workers in the 1960s, in people using haloperidol (Delay 1960). This syndrome was later described in patients treated with other antipsychotics. This is potentially fatal, severe complication as a response to antipsychotics therapy. It occurs in 0.02 to $3 \%$ of patients treated with neuroleptics and is characterised by a number of clinical symptoms, including muscle stiffness, fever and autonomic nervous system disorders (Tural 2010). It is important to quickly diagnose NMS and to stop using antipsychotics because of the severity of complications.

\section{Case description}

A 31-year-old patient was transferred from Psychiatric Ward of Bielański Hospital to Affective Diseases Ward of the Institute of Psychiatry and Neurology with the diagnosis of postpartum psychosis. The patient was hospitalised in the psychiatric ward of Bielański Hospital between 5 September 2016 and 16 September 2016. There was an episode of febrile convulsions in her childhood. The patient was then under the care of a neurologist and psychiatrist for several years; no complications were found and no antiepileptic drugs were taken. During her studies, she received psychiatric and psychological assistance and took antidepressants for a few months. The patient gave a natural birth on 8 July 2016. She has experienced mental deterioration since September 2016. There were difficulties in contacting here; she was illogical in statements, anxious and had problems with child care. She heard knocking sounds that were not there. She saw her mother as a ghost or devil and she had nihilistic delusions.

She was admitted to a psychiatric ward of Bielański Hospital and her treatment with olanzapine at a dose of $20 \mathrm{mg} /$ day started without any significant reaction to it (Bergink et al. 2016, Meltzer-Brody et al. 2018, Bergink et al. 2015, Osborne 2018). The use of lithium carbonate in treatment of patients with postpartum psychosis is considered as a procedure of choice. In the case of the said patient during an attempt to include lithium carbonate, severe skin lesions were observed and the drug was withdrawn after a week. The decision was taken to 
additionally include haloperidol at a dose of $2 \mathrm{mg} /$ day. The patient had a fever up to $38.6^{\circ} \mathrm{C}$ and the laboratory tests showed elevated levels of creatine kinase and myoglobin. The physical examination showed increased muscle tensions. Those symptoms indicated the occurrence of the neuroleptic malignant syndrome.

As soon as neuroleptic malignant syndrome was suspected, antipsychotics were withdrawn and, consequently, lorazepam as well as parenteral hydration were administered. Gradual normalisation of laboratory tests was achieved. During hospitalisation, the patient was consulted neurologically and head CT scan was performed which found no significant abnormalities. The examination of cerebrospinal fluid was also performed - the findings were unremarkable. The patient was referred to the Institute of Psychiatry and Neurology in Warszawa for further treatment and consideration of electroconvulsive therapy (ECT). On admission, the patient was difficult to contact with; she was disorganised in behaviour, illogical in statements, distracted, psycho-motor agitated, in strong anxiety, depressed, and crying. The patient expressed delusions of reference, guilt and punishment as well as persecutory and nihilistic delusions. She also confirmed auditory hallucinations. She required temporary immobilisation due to unpredictable and threatening behaviour. Lorazepam treatment was maintained due to the low TSH level. After internist consultation, the decision was taken to withdraw levothyroxine and include thiamazole at the dose of $20 \mathrm{mg} /$ day.

After the qualification, it was decided to apply electroconvulsive therapy. The patient was not able to give her conscious consent to electroconvulsive therapy. The decision to perform life-saving ECT was taken and the competent court was informed about that. A total of 8 electroconvulsive treatments (both sides of the head, both temples) were performed. The pulse width, frequency and intensity had the same values and equalled respectively: $0.5 \mathrm{~ms}, 10-30 \mathrm{~Hz}$ and $0.98-0.91 \mathrm{~A}$. The course of each procedure was typical with the same doses of anaesthetics and electric charge. Duration of seizures was 20-80 seconds. No complications were observed in the course of treatments (Antosik-Wójcińska and Święcicki 2014, 2015, 2016 i 2017). Propofol was used to anaesthetise the patient and cisatracurium for muscle relaxation. In the event of neuroleptic malignant syndrome, the use of succinylcholine is contraindicated due to the increased risk of malignant hyperthermia (Mayzner-Zawadzka 2009). Due to the use of longer lasting anaesthetics, the patient required temporary intubation and respiratory support. Significant improvement in mental condition was achieved after 6 ECT treatments. Contact with patient was improved, positive symptoms, auditory hallucinations and delusions disappeared. After the end of ECT treatments, it was decided to include aripiprazole at increasing doses up to $5 \mathrm{mg} /$ day. Due to the balanced mental state and lack of recurrence of positive symptoms, it was decided not to increase the dose of aripiprazole to the planned $10 \mathrm{mg} /$ day and the dose of $5 \mathrm{mg} /$ day was left. No complications were observed; vital parameters and level of creatine kinase were checked at regular basis. An increase in TSH $(6.645 \mathrm{IU} / \mathrm{ml})$ level was found in laboratory control tests. Thiamazole dose was reduced to $5 \mathrm{mg} /$ day; levothyroxine was included at a dose of $25 \mu \mathrm{g} /$ day.

As a result of the treatment, psychotic symptoms fully disappeared. In the last days of hospitalisation, the patient was in a balanced mood and psychomotor drive, calm and acting appropriately - without psychotic symptoms and without suicidal thoughts or tendencies. After successful home training, the patient was discharged home and further treatment in outpatient care was recommended.

\section{Discussion}

In this paper, the clinical case of a patient with postpartum psychosis was described for several reasons. Although postpartum psychosis does not occur often, it is the most serious of the peripartum mood disorders. It creates a high risk to the patient's life (and sometimes also people from her environment), requires hospitalisation and fast implementation of the treatment, hence the knowledge of this medical problem seems to be indispensable in the work of psychiatrist. In the described case of Ms. J.M., the patient was diagnosed with neuroleptic malignant syndrome in addition to psychosis. This had an impact on the choice of treatment and on the final decision to begin the electroconvulsive therapy. The authors chose the case of Ms. J.M. as valuable from the educational point of view because of the importance to the discussed clinical problems (postpartum psychosis and NMS) and the desire to show the potential of electroconvulsive therapy in a situation when pharmacological treatment was not only ineffective but also riskier than the use of ECT. Even in this complex case electroconvulsive treatment proved to be a safe and effective method of therapy. According to Palińska et al. (2008), low popularity of ECT method may be related to insufficient knowledge about the efficacy and tolerance of ECT treatments among Polish psychiatrists. An additional difficulty is the wrong perception of electroshocks (both by patients and medical personnel) as inhumane method. This kind of a picture is copied by common opinions and some fiction films (Focht i Kellner 2012). Years of experience of the authors of this paper show that ECT is an optimal and well-tolerated method of treatment in many patients, especially the ones with severe depression and psychosis. 


\section{Wstęp}

Do zaburzeń psychicznych występujących w okresie poporodowym zalicza się najczęściej występujące niewielkie zmiany nastroju typu baby blues, a także zaburzenia o znacznie cięższym przebiegu, takie jak depresja poporodowa, i najrzadszą, ale także najcięższą psychozę poporodową. Z danych statystycznych jednoznacznie wynika, że psychoza poporodowa (połogowa) jest zjawiskiem rzadkim. W populacji ogólnej towarzyszy około 0,1-0,2\% porodów (Stewart i wsp. 1991). Jednocześnie stanowi ona najcięższe z zaburzeń psychicznych pojawiających się w okresie po urodzeniu dziecka (Spinelli 2009, Jaeschke i wsp. 2012). U kobiet ze zdiagnozowanym wcześniej zaburzeniem afektywnym dwubiegunowym lub doświadczoną uprzednio psychozą poporodową częstość występowania jest wielokrotnie większa (Watkins 2009).

Kliniczny obraz pacjentki cierpiącej na psychozę poporodową ukazuje kobietę o „afekcie dziwnym, wycofaną, rozproszoną przez halucynacje słuchowe, nieporadną, zdezorientowaną i w stanie katatonii - lub euforyczną, labilną, o chaotycznej mowie, poruszoną, nadmiarowo aktywną" (Brockington 2004). Objawy psychotyczne mogą występować w formie wyizolowanej lub jako kombinacja z labilnymi zaburzeniami nastroju. Niektórzy eksperci określają psychozę poporodową mianem „psychozy z dezorganizacją funkcjonowania poznawczego” lub „psychotycznych zaburzeń afektywnych z cechami majaczenia" (Spinelli 2009). Zgodnie z niedawno opublikowanymi wynikami holenderskiego badania kohortowego, dominującą składową obrazu klinicznego psychozy poporodowej są najczęściej objawy depresyjne (41\%) (Telles-Correia i wsp. 2018).

Ryzyko doświadczenia psychozy poporodowej wzrasta $\mathrm{u}$ kobiet $\mathrm{z}$ dodatnim wywiadem rodzinnym w kierunku zaburzeń afektywnych dwubiegunowych lub zaburzeń psychicznych w połogu. Ryzyko ponownego epizodu psychotycznego w wyniku kolejnego porodu szacuje się na 30-50\% (Kamperman i wsp. 2017). Mimo braku wyszczególnienia psychozy poporodowej jako odrębnej kategorii diagnostycznej w klasyfikacji DSM 5 (uwzględniono jedynie „zaburzenia nastroju w okresie okołoporodowym z objawami psychotycznymi") wydaje się, że jej obraz kliniczny jest na tyle charakterystyczny i różniący się od pozostałych zaburzeń psychicznych występujących w okresie poporodowym, że należy rozpatrywać ją jako odrębną jednostkę chorobową będącą źródłem szkód zdrowotnych, cierpienia oraz upośledzenia funkcjonalnego (Jablensky 2016, American Psychiatric Association 2013).

Ze względu na swój nagły początek i burzliwy przebieg, ryzyko samobójstwa lub dzieciobójstwa, kobiety z doświadczeniem psychozy w połogu wymagają hospitalizacji psychiatrycznej (Koszewska 2010, Spinelli 2009).

Drugim problemem medycznym omówionym w artykule w kontekście leczenia opisywanej pacjentki jest złośliwy zespół neuroleptyczny (ZZN, NMS - Neuroleptic malignant syndrome). ZZN został pierwszy raz opisany w literaturze przez Delaya i wsp. w latach 60. XX wieku u osób przyjmujących haloperidol (Delay 1960). Później opisano wystąpienie tego zespołu także u osób leczonych innymi lekami przeciwpsychotycznymi. Jest to potencjalnie śmiertelne, ciężkie powikłanie występujące w reakcji na terapię lekami przeciwpsychotycznymi. Występuje ono u 0,02-3\% pacjentów leczonych neuroleptykami i charakteryzuje się szeregiem objawów klinicznych, między innymi sztywnością mięśniową, gorączką oraz zaburzeniami autonomicznego systemu nerwowego (Tural 2010). Z uwagi na ciężkość powikłań ważna jest szybka diagnoza ZZN i odstawienie leków przeciwpsychotycznych.

\section{Opis przypadku}

31-letnia pacjentka przeniesiona do Oddziału Chorób Afektywnych Instytutu Psychiatrii i Neurologii z Oddziału Psychiatrii Szpitala Bielańskiego z rozpoznaniem psychozy poporodowej. Pacjentka była hospitalizowana w oddziale psychiatrii Szpitala Bielańskiego w okresie od 5 do 16 września 2016 roku. W wywiadzie epizod drgawek gorączkowych w dzieciństwie, przez kilka lat pacjentka była wówczas pod opieką neurologa oraz psychiatry, nie stwierdzono powikłań, nie przyjmowała leków przeciwpadaczkowych. W czasie studiów korzystała z opieki psychiatry oraz psychologa, przyjmowała leki przeciwdepresyjne przez kilka miesięcy. Pacjentka w dniu 8 lipca 2016 roku urodziła dziecko, poród siłami natury. Od września 2016 roku nastąpiło pogorszenie stanu psychicznego. Pacjentka była w utrudnionym kontakcie, nielogiczna w wypowiedziach, w silnym niepokoju, miała problemy z opieką nad dzieckiem. Słyszała odgłosy pukania, którego nie było, widziała w matce ducha lub diabła, wypowiadała urojenia nihilistyczne.

W oddziale psychiatrycznym Szpitala Bielańskiego rozpoczęto kurację olanzapiną w dawce $20 \mathrm{mg} / \mathrm{d}$, bez istotnej reakcji na leczenie (Bergink i wsp. 2015 i 2016, Meltzer-Brody i wsp. 2018, Osborne 2018) Leczeniem $\mathrm{z}$ wyboru u pacjentek z psychozą poporodową jest terapia z użyciem węglanu litu. U opisywanej pacjentki przy próbie dołączenia węglanu litu wystąpiły nasilone zmiany skórne, lek po tygodniu odstawiono. Zdecydowano o włączeniu dodatkowo haloperidolu w dawce $2 \mathrm{mg} / \mathrm{d}$. $\mathrm{U}$ pacjentki wystąpiła gorączka do $38,6^{\circ} \mathrm{C}$, w badaniach laboratoryjnych stwierdzono podwyższony poziom kinazy fosfokreatynowej oraz mioglobiny. W badaniu przedmiotowym wykazano zwiększone napięcie mięśni. Występujące objawy wskazywały na wystąpienie złośliwego zespołu neuroleptycznego.

W momencie podejrzenia złośliwego zespołu neuroleptycznego odstawiono leki przeciwpsychotyczne oraz zastosowano leczenie lorazepamem, nawadnianie drogą parenteralną. Uzyskano stopniową normalizację badań 
laboratoryjnych. W czasie hospitalizacji pacjentka była konsultowana neurologicznie, wynik badania TK głowy, nie ujawnił istotnych odchyleń od normy. Wykonano również badanie płynu mózgowo- rdzeniowego - wynik był w normie. Pacjentka została skierowana do Instytutu Psychiatrii i Neurologii w Warszawie w celu dalszego leczenia i rozważenia wykonania zabiegów elektrowstrząsowych. Przy przyjęciu pacjentka była w utrudnionym kontakcie, zdezorganizowana w zachowaniu, nielogiczna $\mathrm{w}$ wypowiedziach, rozkojarzona, pobudzona psychoruchowo, w silnym lęku, niepokoju, w obniżonym nastroju, płaczliwa. Pacjentka wypowiadała urojenia ksobne, prześladowcze nihilistyczne, katastroficzne, winy, kary. Potwierdzała omamy słuchowe. Pacjentka ze względu na nieprzewidywalne i zagrażające zachowanie wymagała czasowego unieruchomienia. Utrzymano leczenie lorazepamem, ze względu na obniżenie poziomu TSH, po konsultacji internistycznej, zdecydowano o odstawieniu lewotyroksyny, włączono tiamazol $20 \mathrm{mg} / \mathrm{d}$.

Po przeprowadzonej kwalifikacji zdecydowano o zastosowaniu leczenia elektrowstrząsami (EW). Pacjentka nie była w stanie wyrazić świadomej zgody na powyższe leczenie. Zdecydowano o wykonaniu zabiegów EW ze wskazań życiowych, o czym powiadomiono właściwy sąd. Wykonano łącznie osiem zabiegów elektrowstrząsowych (EW dwustronne, dwuskroniowe). Szerokość impulsu, częstotliwość i natężenie były w trakcie wszystkich zabiegów takie same i wynosiły odpowiednio: $0,50 \mathrm{~ms}, 10-30 \mathrm{~Hz}$ i 0,98-0,91 A. Przebieg poszczególnych zabiegów był typowy, stosując te same dawki środków anestetycznych oraz ładunku elektrycznego uzyskiwano wyładowania napadowe o czasie trwania 20-80 sekund. Nie obserwowano powikłań w przebiegu zabiegów (Antosik-Wójcińska i Święcicki 2014, 2015, 2016 i 2017). Do znieczulenia pacjentki zastosowano propofol, w celu zwiotczenia mięśni - cisatracurium. W przypadku wystąpienia złośliwego zespołu neuroleptycznego przeciwskazane jest użycie sukcynocholiny, z powodu podwyższonego ryzyka wystąpienia hipertermii złośliwej (Mayzner-Zawadzka 2009). Ze względu na użycie środków anestetycznych o dłuższym okresie działania, pacjentka wymagała czasowej intubacji i wspomagania oddechu. Uzyskano znaczną poprawę stanu psychicznego po szóstym zabiegu EW. Obserwowano poprawę kontaktu, ustąpienie objawów wytwórczych, omamów słuchowych, urojeń. Po zakończonych zabiegach EW, zdecydowano o włączeniu aripiprazolu, w dawkach rosnących do $5 \mathrm{mg} / \mathrm{d}$. Z uwagi na wyrównany stan psychiczny i brak nawrotu objawów wytwórczych zdecydowano się nie zwiększać dawki aripiprazolu do planowanych $10 \mathrm{mg} / \mathrm{d}$ i pozostawiono dawkę $5 \mathrm{mg} / \mathrm{d}$. Nie obserwowano powikłań leczenia, regularnie kontrolowano parametry życiowe, poziom kinazy foskokreatynowej. W kontrolnych badaniach laboratoryjnych stwierdzono podwyższenie wartości TSH (6,645 IU/ml). Zmniejszono dawkę tiamazolu do $5 \mathrm{mg} / \mathrm{d}$, włączono lewotyroksynę $25 \mathrm{mi}$ krogram/d.

W wyniku zastosowanego leczenia uzyskano pełne ustąpienie objawów wytwórczych. W ostatnich dniach hospitalizacji pacjentka była w wyrównanym nastroju i napędzie psychoruchowym, spokojna, dostosowana w zachowaniu. Bez objawów psychotycznych. Bez myśli i tendencji suicydalnych. Po udanych treningach domowych pacjentka została wypisana do domu i zalecono jej dalsze leczenie w warunkach ambulatoryjnych.

\section{Dyskusja}

W artykule zdecydowano się na opis kliniczny przypadku pacjentki z psychozą poporodową z kilku względów. Psychoza poporodowa nie występuje wprawdzie często, jednak stanowi najcięższe z okołoporodowych zaburzeń nastroju, stwarza duże zagrożenie dla życia pacjentki (a czasem również osób z otoczenia), wymaga hospitalizacji i szybkiego wdrożenia leczenia, stąd znajomość tego problemu medycznego i wydaje się w praktyce psychiatry nieodzowna. W opisywanym przypadku u pacjentki J.M. oprócz psychozy rozpoznano złośliwy zespół neuroleptyczny. Miało to wpływ na wybór leczenia i ostateczne podjęcie decyzji o rozpoczęciu terapii elektrowstrząsowej. Autorzy wybrali przypadek pacjentki J.M. jako wartościowy pod kątem edukacyjnym, ze względu na doniosłość omawianych problemów klinicznych (PP i ZZN) oraz chęć ukazania możliwości zastosowania leczenia elektrowstrząsowego, w sytuacji gdy leczenie farmakologiczne było nie tylko nieskuteczne, ale i bardziej ryzykowne niż zastosowanie EW. Nawet w tym skomplikowanym przypadku leczenie elektrowstrząsowe okazało się bezpieczną i skuteczną metodą terapii. Zdaniem Palińskiej i wsp. (2008) mała popularność metody EW może być związana z niedostateczną wiedzą o skuteczności i tolerancji zabiegów EW wśród polskich psychiatrów. Dodatkowym utrudnieniem jest niesłuszne postrzeganie elektrowstrząsów (zarówno przez pacjentów, jak i personel medyczny) jako metody niehumanitarnej - taki ich obraz powielają potoczne opinie i niektóre filmy fabularne (Focht i Kellner 2012). $\mathrm{Z}$ wieloletnich doświadczeń autorów doniesienia wynika, że EW są optymalną i dobrze tolerowana metodą leczenia u bardzo wielu chorych, zwłaszcza pacjentów $\mathrm{z}$ ciężką depresją oraz psychozą. 
Conflict of interest and financial support was not declared. / Nie zgłoszono konfliktu interesów oraz dofinansowania.

The work described in this article has been carried out in accordance with The Code of Ethics of the World Medical Association (Declaration of Helsinki) for experiments involving humans, EU Directive 2010/63/EU for animal experiments, and Uniform Requirements for manuscripts submitted to biomedical journals. / Treści przedstawione $w$ artykule są zgodne z zasadami Deklaracji Helsińskiej, dyrektywami EU oraz ujednoliconymi wymaganiami dla czasopism biomedycznych.

Authors' contributions / Wkład autorów: All authors had an equal contribution to all the stages of the work / Wszyscy autorzy wnieśli równomierny wkład w poszczególne etapy realizacji pracy.

\section{References / Piśmiennictwo}

1. American Psychiatric Association. Diagnostic and statistical manual of mental disorders ( $5^{\text {th }}$ ed.). Washington, DC: American Psychiatric Association, 2013.

2. Antosik-Wójcińska A, Święcicki Ł. Analiza skuteczności i bezpieczeństwa zabiegów elektrowstrząsowych w populacjach przed i po 60. roku życia. Psychiatr Pol 2016; 50(5): 1015-1026.

3. Antosik-Wójcińska AZ, Święcicki Ł. Terapia elektrowstrząsowa - skuteczna i bezpieczna alternatywa dla nieskutecznej farmakoterapii. Psychiatria 2014; 11( 3): 166-170.

4. Antosik-Wójcińska AZ, Święcicki Ł. Zasady kwalifikacji do zabiegów elektrowstrząsowych. Psychiatr Dypl 2015; 12(3): $8-32$.

5. Antosik-Wójcińska A, Chojnacka M, Święcicki Ł. Objawy psychotyczne jako powikłanie przebiegu leczenia elektrowstrząsowego - opis przypadku. Psychiatr Pol 2017; 51(1): 23-27.

6. Bergink V, Burgerhout KM, Koorengevel KM, Kamperman AM, Hoogendijk WJ, Lambregtse-van den Berg MP et al. Treatment of psychosis and mania in the postpartum period. Am J Psychiatry 2015; 172(2): 115-123.

7. Bergink V, Rasgon N, Wisner KL. Postpartum Psychosis: Madness, Mania, and Melancholia in Motherhood. Am J Psychiatry 2016; 173(12): 1179-1188.
8. Brockington I. Postpartum psychiatric disorders. Lancet 2004; 363(9405); 303-310.

9. Delay J. A non-phenothizine and non-reserpine major neuroleptic, haloperidol, in the treatment of psychoses. Ann Med Psychol 1960; 118:145-152.

10. Focht A, Kellner CH. Electroconvulsive therapy (ECT) in the treatment of postpartum psychosis. JECT 2012, 28(1): 31-33.

11. Jablensky A. Psychiatric classifications: validity and utility. World Psychiatry 2016; 15(1): 26-31.

12. Jaeschke R, Siwek M, Dudek D. Poporodowe zaburzenia nastroju - update 2012. Neuropsychiatr Neuropsychol 2012; 7(3): 113-121.

13. Kamperman AM, Veldman-Hoek MJ, Wesseloo R, Robertson Blackmore E, Bergink V. Phenotypical characteristics of postpartum psychosis: A clinical cohort study. Bipolar Disord 2017; 19(6): 450-457.

14. Koszewska I. O depresji w ciąży i po porodzie. Wydawnictwo Lekarskie PZWL, Warszawa 2010.

15. Mayzner-Zawadzka E. Anestezjologia kliniczna z elementami intensywnej terapii i leczenia bólu. PZWL, Warszawa 2009; wyd.1.

16. Meltzer-Brody S, Howard LM, Bergink V, Vigod S, Jones I, Munk-Olsen T et al. Postpartum psychiatric disorders. Nat Rev Dis Primers 2018; 4: 18022.

17. Osborne LM. Recognizing and Managing Postpartum Psychosis: A Clinical Guide for Obstetric Providers. Obstet Gynecol Clin North Am 2018; 45(3): 455-468.

18. Palińska D, Gazdag G, Sobów T et al. Leczenie elektrowstrząsowe w Polsce w 2005 roku - wyniki ankiety przeprowadzonej w polskich szpitalach psychiatrycznych. Psychiatr Pol 2008; 6: 825-839.

19. Spinelli MG. Postpartum psychosis: detection of risk and management. Am J Psychiatry 2009; 166(4): 405-408.

20. Stewart D, Klompenhouwer J, Kendell R et al. Prophylatic lithium in puerperal psychosis: the experience of three centres. Br J Psychiatry 1991; 158: 393-397.

21. Telles-Correia D, Saraiva S, Gonçalves J. Mental Disorder-The Need for an Accurate Definition. Front Psychiatry 2018; 9: 64.

22. Tural U. Clinical and pharmacologic risk factors for neuroleptic malignant syndrome and their association with death. A case-control study. Psychiatry Clin Neurosci 2010; 79-87.

23. Watkins ME, Newport DJ. Psychosis in pregnancy. Obstetrics Gynecology 2009; 113(6): 1349-1353. 